\title{
HAWANA
}

A Phonological Oddity in the Austronesian Area: Ejectives in Waimoa

Author(s): John Hajek and John Bowden

Source: Oceanic Linguistics, Vol. 41, No. 1 (Jun., 2002), pp. 222-224

Published by: University of Hawai'i Press

Stable URL: http://www.jstor.org/stable/3623333

Accessed: 02/06/2010 02:53

Your use of the JSTOR archive indicates your acceptance of JSTOR's Terms and Conditions of Use, available at http://www.jstor.org/page/info/about/policies/terms.jsp. JSTOR's Terms and Conditions of Use provides, in part, that unless you have obtained prior permission, you may not download an entire issue of a journal or multiple copies of articles, and you may use content in the JSTOR archive only for your personal, non-commercial use.

Please contact the publisher regarding any further use of this work. Publisher contact information may be obtained at http://www.jstor.org/action/showPublisher?publisherCode=uhp.

Each copy of any part of a JSTOR transmission must contain the same copyright notice that appears on the screen or printed page of such transmission.

JSTOR is a not-for-profit service that helps scholars, researchers, and students discover, use, and build upon a wide range of content in a trusted digital archive. We use information technology and tools to increase productivity and facilitate new forms of scholarship. For more information about JSTOR, please contact support@jstor.org. 


\title{
Squib
}

\section{A Phonological Oddity in the Austronesian Area: Ejectives in Waimoa ${ }^{1}$}

\author{
John Hajek \\ UNIVERSITY OF MELBOURNE
}

John Bowden

AUSTRALIAN NATIONAL UNIVERSITY

\begin{abstract}
Details are provided about a series of ejective stops in Waimoa, spoken in East Timor. Not uncommon in other parts of the world, ejective stops are exceptionally rare within the whole Austronesian area.
\end{abstract}

We report here on the existence of voiceless ejective stops in Waimoa (also Waima'a), an Austronesian language spoken in East Timor. This is only the second Austronesian language for which ejectives have ever been reported.

According to the most recent edition of Ethnologue (Grimes 2000), Waimoa is a member of the Nuclear Timor subgrouping within the larger Timor grouping inside Central Malayo-Polynesian. ${ }^{2}$ The language is most closely related to Kairui-Midiki and $\mathrm{Habu}$, and has approximately 3,000 speakers living in a small number of villages on the Baucau plateau on the northeastern coast of East Timor. Neighboring languages are Galoli (Austronesian) to the west, Kairui-Midiki to the south, and Makasae (non-Austronesian) concentrated in and around the city of Baucau immediately to the east. Tetun Dili is widely used as a lingua franca in interethnic communication in this whole area-particularly with the Makasae. Waimoa speakers report that Waimoa and Kairui-Midiki are mutually intelligible, and may be used as alternatives to Tetun between speakers of these languages.

Field data for this report were collected in the village of Caisido, ten kilometers west of Baucau. Initial analysis of our data indicates that Waimoa has the following contrastive system of stops:

(I) voiceless unaspirated voiceless aspirated voiceless ejective voiced plain

$\begin{array}{llll}\mathrm{p} & \mathrm{t} & \mathrm{k} & \text { ? } \\ \mathrm{p}^{\mathrm{h}} & \mathrm{t}^{\mathrm{h}} & \mathrm{k}^{\mathrm{h}} & \\ \mathrm{p} & \mathrm{t} & \mathrm{k} & \\ \mathrm{b} & \mathrm{d} & \mathrm{g} & \end{array}$

(Near-)minimal sets can be found incorporating all stop types at three places of articulation-including the three ejective stops ( $\left.\mathrm{p}^{\prime}, \mathrm{t}^{\prime}, \mathrm{k}^{\prime}\right)$. The result is a four-way stop contrast system at velar, coronal, and bilabial place.

I. The authors would very much like to express their appreciation to language helpers, Orlando Belo and, in particular, Mauricio D. A. C. Belo, for their assistance.

2. Hull's (1998) more detailed and reliable classification establishes a Timoric group within which Kairui, Midiki, Naueti, and Waimoa are all likely dialects of the same language. 
$\begin{array}{ll}\text { (2) a. kama 'bed' } \\ k^{\mathrm{h}_{\mathrm{a}} \mathrm{ma}} & \text { 'eat already' } \\ \text { k'ama } & \text { 'scratch' } \\ \text { gama } & \text { 'shark' }\end{array}$
b. tegi 'kneel'
theki 'gecko'
t'eri 'belch'
$\operatorname{degu}^{3}$ 'night'

c. porti 'strong'
phalta 'lack' $_{\text {p'ari 'big' }}$
baibain 'usually'

The voiceless glottal stop is contrastive in intervocalic position. As it is marginal to discussion here, it will not be considered further.

Ejectives in Waimoa are articulated clearly and in a manner that is consistent with the phonetic description provided by Ladefoged and Maddieson (I996) and Laver (1994), among others. While there is complete closure of the oral cavity, there is simultaneous closure and raising of the larynx. The latter results in compression in the oral cavity. Oral closure is then released, triggering a stop burst that is markedly louder and stronger than that found in other kinds of stops. The acoustic effect is of a loud pop on release.

A number of observations can be made about the distributional characteristics of ejectives in Waimoa. They are of relatively limited frequency, and occur almost always in word-initial position. They never appear before other consonants, unlike voiceless unaspirated stops, for example, krini 'dry' and klohi 'soft'. We have so far recorded only one example of an ejective stop appearing either word-medially or in post-consonantal position: namp'ita 'lightning'. The combination sa k'ie 'intestinal worm' with post-vocalic $k$ ' is analyzed as a generic-specific compound, where $s a$ is a generic term referring to insects and $k^{\prime} i e$ denotes an intestinal worm in particular (cf. sa p'au 'mosquito'). One final phonotactic trait of ejectives, shared also by voiceless aspirates, is that they can appear only once in a word: $p$ 'obo 'wet' and k'akan 'sago' in contrast to other stops: bobo 'grandfather' (voc.), and koko 'to try'.

From a typological perspective, voiceless ejective stops and fricatives appear relatively frequently in the world's languages. Maddieson (I984) found them to occur in 18 percent of his large cross-linguistic sample, spread across a wide and diverse area from the Americas, across parts of Africa to the Caucasus, and beyond. What is striking is the marked absence of ejectives from the Austronesian-speaking area. According to most recent estimates (Grimes 2000), there are some I,262 Austronesian languages. Yet only one other Austronesian language, Yapese, has previously been reported to have ejectives (see Blust I980, Hsu I969, Jensen I977). Yapese is spoken in Micronesia, and there is no reason to believe that the existence of ejective stops in Yapese and Waimoa is in any way directly related. Ejectives in both languages have clearly developed independently. It is premature to speculate on the origins of ejectives in Waimoa, because our knowledge of the language remains sketchy, but we can confirm at this stage that ejectives in Waimoa are not the result of language contact, as they are found neither in neighboring non-Austronesian Makasae nor in Austronesian Galoli or Kairui-Midiki. ${ }^{4}$

3. As in many other East Timorese languages, e.g., Tetun, voiced $d$ tends to be retracted to postalveolar place, in contrast to the dental or alveolar articulation of voiceless coronals.

4. The development of ejectives in Yapese-a language that has been more extensively studied-has not yet been fully described (but see Blust 1980 and Ross 1996 for some early indications). 


\section{REFERENCES}

Blust, Robert. I980. More on the origins of glottalic consonants. Lingua 52:1 25-I 56.

Grimes, Barbara, ed. 2000. Ethnologue. I 4th ed. Dallas: Summer Institute of Linguistics.

Hsu, Robert Wen. 1969. Phonology and morphophonemics of Yapese. Ph.D. dissertation, University of California, Berkeley.

Hull, Geoffrey. I998. The basic lexical affinities of Timor's Austronesian languages: A preliminary investigation. Studies in the languages and cultures of East Timor I:97-202.

Jensen, John T. I977. Yapese reference grammar. Honolulu: The University Press of Hawai'i.

Ladefoged, Peter, and Ian Maddieson. 1996. Sounds of the world's languages. Oxford: Blackwell.

Laver, John. I994. Principle of phonetics. Cambridge: Cambridge University Press.

Maddieson, Ian. 1984. Patterns of sounds. Cambridge: Cambridge University Press.

Ross, Malcolm. I996. Is Yapese Oceanic? In Reconstruction, classification, description: Festschrift in honour of Isidore Dyen, ed. by Bernd Nothofer, I 2 I-166. Hamburg: Abera.

John Hajek

Department of French and Italian Studies

The University of Melbourne

VIC 30 Io Australia

j.hajek@language.unimelb.edu.au
John Bowden

Department of Linguistics

Research School of Pacific and Asian Studies

The Australian National University

Canberra ACT 0200 Australia

john.bowden@anu.edu.au 